\title{
Role of women entrepreneurship in agro processing centre-A case study in Tumkur district
}

\author{
L.G. RAMYA, V. MOKSHA, B.S. LAKSHMAN REDDY AND G.N. NAGARAJA
}

Received : 25.08.2017; Revised : 08.09.2017; Accepted : 22.09.2017

\begin{abstract}
Agro processing could be defined as set of techno-economic activities carried out for conservation and handling of agricultural produce and to make it usable as food, feed, fibre, fuel or industrial raw material. The potential for agro-industrial development in the developing countries is largely linked to the relative abundance of agricultural raw materials and low-cost labour in most of them. Despite their important contribution to overall and agricultural development, agro processing industries in India is still at infant stage. In the regard, an Agro processing centre (APC) located at Tumkur district was identified for the purpose of the study. The study was conducted in Kuchangi village in Tumkur taluk of Tumkur district during 2015.SHG members of Sri Lakshmidevi Sthree Shakthi Sangha in Kuchangi village were interviewed using a pre-tested schedule. The results revealed that there is positive growth rate in savings of APC members, the highest growth rate was achieved in 2014 i.e., 155 per cent and the per capita savings of members also recorded an increase during the study period. From this, it can be concluded that with a small initial investment, APC will not only provide additional and regular income to SHG but also provide employment and women empowerment.
\end{abstract}

KEY WORDS : Role of women, Processing centre, Agro-industrial, APC

\section{MEMBERS OF THE RESEARCH FORUM}

Correspondence to:

G.N. NAGARAJA, Department of Agricultural Marketing, Cooperation and Business Management, College of Agriculture, University of Agricultural Sciences, GKVK, BANGALORE (KARNATAKA) INDIA Email: dr_nagarajag@ @otmail.com

\section{Authors' affiliations:}

L.G. Ramya,Xceedance, Indiqube Building, Kadubeesanahalli, BANGALORE (KARNATAKA) INDIA

Email : lgramya02@gmail.com

V. Moksha, Department of Agricultural Marketing, Cooperation and Business Management, University of Agricultural Sciences, GKVK, BANGALORE (KARNATAKA) INDIA

Email : mokshareddy259@gmail.com

B.S. Lakshman Reddy, Department of Agricultural Extension, University of Horticultural Sciences, BAGALKOTE (KARNATAKA) INDIA Email : bslreddyextn@gmail.com
How to cite this paper : Ramya, L.G., Moksha, V., Reddy, B.S. Lakshman and Nagaraja, G.N. (2017). Role of women entrepreneurship in agro processing centre-A case study in Tumkur district. Internat. J. Com. \& Bus. Manage, 10(2) : 218-225, DOI: 10.15740/HAS/IJCBM/10.2/218-225. 